\title{
Perceived Elitist and State-Centric Regional Integration Process: Impact on Public Opinions for the Formation of ASEAN Community
}

\author{
Guido Benny \\ Ravichandran Moorthy \\ Sity Daud \\ Zarina Othman \\ School of History, Politics and Strategy, Universiti Kebangsaan Malaysia, 43600 UKM Bangi, Selangor Darul Ehsan, Malaysia \\ Email: guidobenny@gmail.com
}

\section{Doi:10.5901/mjss.2015.v6n2s1p203}

\section{Abstract}

Scholars argue that ASEAN is a community of nations and not a community of people. Decision making in ASEAN have been concentrated within the higher echelon of leadership, with little public engagement. This article analyses whether public attitudes and supports for the formation of ASEAN Community were affected by the perception of elitist formation of the regionalism initiative. It employs public opinion surveys to gather feedback from respondents about issues under study. The surveys conducted in eleven cities in Indonesia, Malaysia and Singapore. Statistical analyses were employed for the study. Several findings were discovered; Firstly, it finds the respondents perceived that the formation of ASEAN Community is beneficial. Secondly, they strongly support the formation of the regional community. Thirdly, the formation is perceived as elitist and state-centric as they did not involve the people. Finally, the study concludes that the perceptions of elitist state-centric formation of ASEAN Community do have effects on the perception of benefits and supports. As such, the study implies that ASEAN should actively involve the public through public opinion surveys for its policies and issues of its establishment.

Keywords: Perception of regionalism process, ASEAN Community, ASEAN, Regionalism, Perceived benefits of regional integration, Supports for regionalism initiatives

\section{Introduction}

At the end of 2015, the Southeast Asian region will begin the implementation of ASEAN Community. The regional community was firstly announced in the ASEAN Vision 2020, envisioning the ASEAN Community as a "concert of Southeast Asian nations, outward looking, lives in peace, stability and prosperity, bonded together in partnership in dynamic development and in a community of caring societies" (ASEAN Secretariat, 1997). The concept of ASEAN Community was more clearly enunciated in the Bali Concord II, issued at the Ninth ASEAN Summit in Bali (Indonesia) on $7^{\text {th }}$ December 2003 (ASEAN Secretariat, 2003). The ASEAN Community will comprise of three pillars, namely the ASEAN Political Security Community, the ASEAN Economic Community, and the ASEAN Socio-Cultural Community aspired to be effective in 2015. The three pillars were designed as closely intertwined and mutually reinforcing for the purpose of ensuring durable peace, stability and shared prosperity in the region.

Regarding the formation of ASEAN Community, many regional observers were sceptical as they consider the idea as 'too good to be true' when taking into account the current regional situation. For example, Kavi Chongkittavorn - a Senior Fellow at the Institute of Strategic and International Studies, Chulalongkorn University - argued, "Nobody expects ASEAN to move in the direction of the EU. But as with the EU, the realization of an AC (sic, ASEAN Community) will need more than just words and niceties" (Chongkittavorn, 2006). The same scepticism was shown by Ikrar Nusa Bakti - a former chairman of the Department of Political Studies at the Indonesian Institute of Science (LIPI) - who argued that, "ASEAN has long been known as an elitist organization, controlled by bureaucrats and politicians. ASEAN should belong to the general public, so the organization can be relevant to its members and other states outside the region".

It seems that the general public of ASEAN countries has not been involved in the establishment of ASEAN Community. History in the European integration shows that the public involvement is crucial. The EU's current status and its success in economic, political and social integration have clearly been the outcome of consensus, active involvement 
of the public and policies based on the Eurobarometer surveys on the grassroots. The idea of a European community (EC) took years to materialize since the process did not only involve policy makers but also the public's positive perception, acceptance, and understanding. Even prior to the realization and formalization of the EU, policy makers and academicians had conducted extensive studies to determine the public's understanding and acceptance of the idea of a regional community.

For ASEAN integration, however, it is worrying that, besides the absence of public opinion measures in the region, studies conducted based on the opinion of the public are scanty. It can be argued that most of the literature on the concept and ideas of an ASEAN Community has relied on academic opinion of several scholars. There have been only some studies so far on the public opinion towards ASEAN Community. The lack of the public's perspectives and responses to the concept of ASEAN Community has resulted in a gap in the literature on ASEAN regionalism.

In addition to that, thorough review on the ASEAN regionalism literature found no specific reference to the effect of perceived elitist and state-centric formation on public attitudes towards the formation of ASEAN Community. Studies on ASEAN are numerous, yet they were conducted using the elite decision making approach for assessing the establishment processes or the social, political, and economic challenges of ASEAN (Acharya 2003; Guerrero 2008; Hew 2007) as well as the readiness of the business sector for ASEAN Community (Abidin, Loh and Aziz 2012; Mugijayani and Kartika 2012). Studies involving public opinion in ASEAN are quite rare - only a few studies so far exist conducted by Benny, Rashila and Tham (2014); Abdullah and Benny (2013), Abdullah, Benny and Din (2010), Benny and Abdullah (2011), Moorthy and Benny (2012a, 2012b, and 2013); and Thompson and Thianthai (2008).

The purpose of this article is to discuss, evaluate and analyze public supports, perceived benefits, and opinions towards the proposed formation of ASEAN Community. This study argues that public supports are influenced positively by the respondents' perception regarding the benefits of regional integration. The study also argues that public supports and perception regarding the ASEAN Community are influenced the opinion regarding the formation process of the regional community. Thus, the study is intended to contribute to the body of knowledge of regional integration, especially on the role that the public attitudes, opinions and aspirations play in the Southeast Asian regionalism.

\section{Studies on Perceived Elitist and State-centric ASEAN and Attitude towards Regional Economic Integration}

Previous researches have not systematically examined how perception of state-centric and elitist process in the formation of ASEAN Community relates with perception of benefits and supports for the formation. Despite many scholarly discussions about perception of state-centric and elitist process ASEAN and attitudes towards economic regional integration, the relationship between those variables has not been clearly elucidated.

Pertaining to ASEAN, some scholarly works in regional studies have remarked that the regional integration process appears to be both elitist and state-centric, with little effort thus far to consult the voices of the masses (Acharya, 2003 \& 2009; Sung, 2010; Thi, 2008). The conception of "community" in ASEAN is so elitist as it lacks one of the fundamental components of success in the European Community: the involvement of the general public (Abdullah and Benny, 2013; Moorthy and Benny, 2012a, 2012b and 2013; Benny and Abdullah, 2011; Benny, Abdullah and Din, 2010; Benny, Rashila and Tham, 2014).

Literatures on regionalism - the transactionalist, neo-functionalist and democratic theories -although at variance in their explanation on which attitudes and support are needed for the success of regional integration - have shown that opinions and participation of the general public would determine the success of such efforts (Moorthy and Benny, 2012 and 2013; Benny and Abdullah, 2011; Benny, Rashila and Tham, 2014; Collins, 2008). C.J. Wilson (2004) argues that one of the major barriers to regional integration in North America is the lack of public support for closer integration. Similarly, M.J. Gabel (1998) asserts that public attitudes are an important component of European integration because they provide the political foundation for integration as well as shape and constrain the process of the integration. Furthermore, the endurance of the EU political system vitally depends on public compliance with and acceptance of EU law which lacks a supranational means of enforcement. Jones argues that public attitudes are important both for the euro and the European Central Bank because of the problem of legitimacy in regional financial policy (Jones, 2009). Furthermore, the persistent work of Eurobarometer - that have assessed public attitudes, opinions, and aspirations towards European regional integration for more than 38 years - shows us that public attitudes, opinions, and aspirations are important to be assessed. 


\section{Research Design and Methods}

\subsection{Measures, Sample and Survey Procedures}

The study was based on the surveys conducted in three ASEAN countries, namely Indonesia, Malaysia and Singapore. The purpose of the surveys is to gather information at grassroots level on attitudes, opinions and aspirations for the ASEAN Community. In the three countries, the surveys were conducted in eleven major cities countries (Indonesia: Greater Jakarta, Makassar, Medan, Surabaya and Pontianak; Malaysia: Greater Kuala Lumpur, Penang, Melaka, Johor Bahru, and Kota Kinabalu; and Singapore). The cities were purposively chosen in terms of their importance and influence to the economy, polity, and socio-culture of the countries and their connectedness to other countries in the region. To measure the responses, several structured close-ended and open-ended questionnaires in were employed.

Because of the differences in lingua-franca in the three countries, questionnaires were made available in three languages (Bahasa Indonesia, Bahasa Malaysia, and English). The questionnaires were checked carefully by the professional editors in three languages to ensure that the original ideas of the questions were not diluted. The questionnaires were screened in pre-tests, involving 30 respondents for each type of questionnaires, to check the structure of the questions and the understanding of target respondents.

To collect data, surveys and intensive interviews were conducted between June to December 2009, involving 551 respondents in Indonesia, 451 respondents in Malaysia and 294 respondents in Singapore; so a total of 1,256 respondents were involved in the study. They were selected by convenience quota sampling, trying to balance the proportion of students and staffs respondents. The respondents with a minimum of university student education background were required due to the complicated questions structure and the requirement of critical thinking of the respondents. The choice of the specific type of the respondents was thought to reflect the reality of them who will be active in the establishment of the ASEAN Community.

Table 1 shows the details of respondents. The Indonesian respondents came from Greater Jakarta (37.1\%), Medan (15.7\%), Surabaya (15.7\%), Pontianak (15.7\%), and Makassar (15.9\%). The Malaysian respondents resided in Greater Kuala Lumpur (27.7\%), Melaka (20.6\%), Penang (19.3\%), Johor Bahru (17.5\%), and Kota Kinabalu (14.9\%). Those surveyed consisted of $50.8 \%$ male and $49.2 \%$ female. The majority of them are younger mature $(75.4 \%)$, single $(70.7 \%)$, with undergraduate education background (72.4\%) and with lower to middle level of household expenditure. Students (46.2\%), lecturers (21.9\%), and private-sector employees (15.1\%) were three major occupations of respondents in the three countries (See: Moorthy and Benny, 2013: 406).

Table 1. Profile of Respondents

\begin{tabular}{|c|c|c|c|c|c|c|c|}
\hline \multirow{3}{*}{ Number of the respondents } & \multicolumn{7}{|c|}{ Countries } \\
\hline & \multicolumn{2}{|c|}{ Indonesia } & \multicolumn{2}{|l|}{ Malaysia } & \multicolumn{2}{|c|}{ Singapore } & Overall \\
\hline & 426 & & 401 & & 213 & & 1,040 \\
\hline & Jakarta & 37.1 & Kuala Lumpur & 27.7 & & & \\
\hline & Medan & 15.7 & Melaka & 20.6 & & & \\
\hline Cities of domicile & Surabaya & 15.7 & Penang & 19.3 & Singapore & 100 & \\
\hline & Pontianak & 15.7 & Johor Bahru & 17.5 & & & \\
\hline & Makassar & 15.9 & Kota Kinabalu & 14.9 & & & \\
\hline \multicolumn{8}{|l|}{ Gender } \\
\hline Male (\%) & 48.0 & & 51.1 & & 55.5 & & 50.8 \\
\hline Female (\%) & 52.0 & & 48.9 & & 44.5 & & 49.2 \\
\hline \multicolumn{8}{|l|}{ Age (years old) } \\
\hline Younger mature, 18 to $34(\%)$ & 83.8 & & 73.1 & & 63.7 & & 75.4 \\
\hline Older mature, 35 to $49(\%)$ & 13.4 & & 20.9 & & 22.0 & & 18.1 \\
\hline Senior, 50 or more (\%) & 2.8 & & 6.0 & & 14.3 & & 6.5 \\
\hline \multicolumn{8}{|l|}{ Marital status } \\
\hline Single (\%) & 74.6 & & 70.7 & & 63.6 & & 70.7 \\
\hline Married (\%) & 25.2 & & 28.2 & & 35.7 & & 28.6 \\
\hline Widow/er (\%) & 0.2 & & 1.1 & & .7 & & 0.7 \\
\hline \multicolumn{8}{|l|}{ Formal education } \\
\hline Undergraduate (\%) & 89.2 & & 67.0 & & 50.7 & & 72.4 \\
\hline Master degree (\%) & 10.2 & & 22.6 & & 14.4 & & 15.7 \\
\hline $\mathrm{PhD}(\%)$ & 0.6 & & 10.4 & & 34.9 & & 12.0 \\
\hline
\end{tabular}




\begin{tabular}{lcccc}
\hline & \multicolumn{4}{c}{ Countries } \\
\cline { 2 - 5 } & Indonesia & Malaysia & Singapore & Overall \\
\hline Occupation & & & 40.8 & 21.9 \\
Lecturer (\%) & 7.1 & 26.4 & 5.8 & 7.0 \\
Civil servant (\%) & 8.2 & 6.4 & 2.0 & 15.1 \\
Private-sector employee (\%) & 33.5 & 2.7 & 0.0 & 1.8 \\
Soldier/ Police (\%) & 0.0 & 5.1 & 0.7 & 1.4 \\
Doing business (\%) & 3.1 & 0.0 & 0.3 & 0.8 \\
Housewife (\%) & 1.8 & 0.0 & 42.9 & 46.2 \\
Student (\%) & 40.9 & 54.3 & 0.0 & 1.8 \\
Not working (\%) & 3.1 & 1.3 & 7.5 & 4.1 \\
Other (\%) & 2.4 & 3.8 &
\end{tabular}

\subsection{Measuring Dependent Variables}

The dependent variables for the present study are perceived benefits of the ASEAN Community and the supports for its formation. Because it is assumed that not all respondents know the concept of ASEAN Community, a brief description of the concept of the ASEAN regional integration was conveyed as follow:

"The leaders of ASEAN Countries signed the Bali Concord II on 7th October 2009. The essence of the concord was the acceptance of the ASEAN Community concept that will be effectively implemented in 2015. The concord defines the ASEAN Community as a concert of Southeast Asian nations, bonded together in partnership in dynamic development and in a community of caring societies, committed to upholding cultural diversity and social harmony. The ASEAN Community will comprise three pillars, namely the ASEAN Political Security Community, ASEAN Economic Community, and ASEAN Socio-Cultural Community that are closely intertwined and mutually reinforcing for the purpose of ensuring durable peace, stability and shared prosperity in the region."

After the brief description of the ASEAN Community, the questionnaires forwarded the instruction for circling the most appropriate number of the level of respondent' agreement for each statement, followed by five statements for measuring their perceived benefits of the ASEAN Community and four statements for the support for the formation of ASEAN Communit. The complete description of the questions are presented at the Table 2 while the descriptive statistics of this variable are conveyed in Table 3 and 4.

Table 2. Survey questions wording of Dependent and Independent Variables

\begin{tabular}{cc}
\hline Dependent Variable 1: Perceived benefits of the ASEAN Community \\
\hline 1 & $\begin{array}{l}\text { "My country will get benefits from the membership of the ASEAN Community" } \\
\text { (1) Strongly disagree; (2) Disagree; (3) Not agree nor disagree; (4) Agree; (5) Strongly agree. }\end{array}$ \\
\hline 2 & "The establishment of ASEAN Community is good for my country and the people" \\
& (1) Strongly disagree; (2) Disagree; (3) Not agree nor disagree; (4) Agree; (5) Strongly agree. \\
\hline 3 & $\begin{array}{l}\text { "The formation of the ASEAN Political Security Community (APSC) is good for my country and society" } \\
\text { (1) Strongly disagree; (2) Disagree; (3) Not agree nor disagree; (4) Agree; (5) Strongly agree. }\end{array}$ \\
\hline 4 & $\begin{array}{l}\text { "My country will get benefits from membership in the ASEAN Economic Community (AEC)" } \\
5\end{array}$ \\
\hline $\begin{array}{l}\text { The formation of the ASEAN Socio-Cultural Community (ASCC) is good for the social and cultural development of my country } \\
\text { (1) Strongly disagree; (2) Disagree; (3) Not agree nor disagree; (4) Agree; (5) Strongly agree. }\end{array}$ \\
\hline 1 \\
\hline $\begin{array}{l}\text { "I support the formation of the ASEAN Community." } \\
\text { (1) Strongly disagree; (2) Disagree; (3) Not agree nor disagree; (4) Agree; (5) Strongly agree. }\end{array}$ \\
$\begin{array}{l}\text { "I support the formation of the APSC" } \\
\text { (1) Strongly disagree; (2) Disagree; (3) Not agree nor disagree; (4) Agree; (5) Strongly agree. }\end{array}$ \\
\hline $\begin{array}{l}\text { "I support the formation of the AEC" } \\
\text { (1) Strongly disagree; (2) Disagree; (3) Not agree nor disagree; (4) Agree; (5) Strongly agree. }\end{array}$ \\
\hline $\begin{array}{l}\text { "I support the formation of the ASCC" } \\
\text { Strongly disagree; (2) Disagree; (3) Not agree nor disagree; (4) Agree; (5) Strongly agree. }\end{array}$ \\
\hline Independent Variable: Perception on the Formation Process of ASEAN Community \\
\hline $\begin{array}{l}\text { "The formation of the ASEAN Community is the initiative of the elite and does not involve the people" } \\
\text { (1) Strongly disagree; (2) Disagree; (3) Not agree nor disagree; (4) Agree; (5) Strongly agree. }\end{array}$ \\
$\begin{array}{l}\text { "The formation of ASEAN Community is merely a declaration of ASEAN leaders not fruitful to the people" } \\
\text { (1) Strongly disagree; (2) Disagree; (3) Not agree nor disagree; (4) Agree; (5) Strongly agree. }\end{array}$ \\
\hline
\end{tabular}




\subsection{Measuring Predictors: Perception on the Formation Process of ASEAN Community}

The study took from several scholarly works - like Amitav Acharya (2003), Claire Sutherland (2009), Guido Benny, Rashila Ramli and Than Siew Yean (2014), Jenina Joy Chavez (2007), Kamarulnizam Abdullah and Guido Benny (2013), Kamarulnizam Abdullah, Guido Benny, and Mohamed Anwar Omar Din (2013), Lily Zubaidah Rahim (2008), Melly Caballero-Anthony (2009), Ravichandran Moorthy and Guido Benny (2013), Rodolfo Severino (2007), Sung Won Kim (2010), and Thi Thu Huong Dang (2008) - that affirmed the ASEAN Community formation process as elitist and statecentric. Based on those studies, the survey constructed two indicators for measuring the perception of the elitist and state-centric formation process of ASEAN Community. The complete description of the questions are presented at the Table 2 while the descriptive statistics of this variable are conveyed in Table 5.

\section{Method of Analysis}

The study has used Pearson Chi-Square test (Pagano, 2013; Gravetter \& Wallnau, 2013) to estimate effect of the independent variable (perception of elitist and state-centric formation process) on the dependent variables (perceived benefits of ASEAN Community and the support for its formation). Since the study aims to test the effect of the independent variable on nine indicators of the two dependent variables, there are nine Pearson Chi-Square tests conducted (See Table 6).

\section{Results and Discussion}

\subsection{Perceived Benefits of the ASEAN Community}

The variable of 'perceived benefits' was defined as respondents' perception of what the proposed ASEAN Community and its three pillars may deliver for the benefits of the region, their country and the people. There were some previous studies conducted on the perceived benefits of regional integration, but none is within the Southeast Asian regionalism context.

Table 3: Perceived benefits of the ASEAN Community

\begin{tabular}{|c|c|c|c|c|c|c|}
\hline \multirow{4}{*}{$\begin{array}{l}\text { My country will get benefits from the membership of the ASEAN } \\
\text { Community. }\end{array}$} & \multirow[b]{3}{*}{$\bullet$} & \multirow[b]{3}{*}{ Mode } & \multicolumn{4}{|c|}{ Respondents } \\
\hline & & & \multicolumn{4}{|c|}{ Malaysia Indonesia Singapore Average } \\
\hline & & & Agree & Agree & Agree & Agree \\
\hline & $\bullet$ & Mean & $\begin{array}{c}4.04 \\
\text { Agree }\end{array}$ & $\begin{array}{c}4.01 \\
\text { Agree }\end{array}$ & $\begin{array}{c}.91 \\
\text { Agree }\end{array}$ & $\begin{array}{c}4.00 \\
\text { Agree }\end{array}$ \\
\hline \multirow{3}{*}{$\begin{array}{l}\text { The establishment of ASEAN Community is good for my country } \\
\text { and the people. }\end{array}$} & $\bullet$ & Mode & Agree & Agree & Agree & Agree \\
\hline & $\bullet$ & Mean & 4.07 & 4.08 & 3.94 & 4.05 \\
\hline & & & Agree & Agree & Agree & Agree \\
\hline \multirow{3}{*}{ The formation of the APSC is good for my country and society. } & $\bullet$ & Mode & Agree & Agree & Agree & Agree \\
\hline & $\bullet$ & Mean & 3.94 & 3.99 & 3.82 & 3.94 \\
\hline & & & Agree & Agree & Agree & Agree \\
\hline \multirow{3}{*}{ My country will get benefits from membership in AEC. } & $\bullet$ & Mode & Agree & Agree & Agree & Agree \\
\hline & $\bullet$ & Mean & 3.91 & 3.82 & 3.82 & 3.86 \\
\hline & & & Agree & Agree & Agree & Agree \\
\hline \multirow{3}{*}{$\begin{array}{l}\text { The formation of ASCC is good for the social and cultural } \\
\text { development of my country. }\end{array}$} & $\bullet$ & Mode & Agree & Agree & Agree & Agree \\
\hline & $\bullet$ & Mean & 3.87 & 3.84 & 3.78 & 3.84 \\
\hline & & & Agree & Agree & Agree & Agree \\
\hline
\end{tabular}

Source: Result of field surveys conducted by the researchers

In general, the respondents perceived the formation of ASEAN Community as beneficial and positive for the region (see Table 3). More than $80 \%$ respondents perceived the proposed formation as beneficial to their country and the people and optimistic that their country would benefit from membership in the Community. Furthermore, about three-quarters of them expressed their belief to the objective of ASEAN Community mentioned in the 2003 Declaration of Bali Concord II - a 
Community that is able to create a partnership in dynamic development and a community of caring societies with diverse cultures and social harmony (ASEAN Secretariat, 2003).

ASEAN Political Security Community (APSC) is the first pillar of the proposed ASEAN Community. The ASEAN Vision 2020 stated that APSC is intended as the institution where the members will live at peace with each other where the causes for conflict have been eliminated, through abiding respect for justice and the rule of law and through the strengthening of national and regional resilience (ASEAN Secretariat, 1997). Further, Declaration of Bali Concord II marked out seven areas where intensified political and security cooperation is to take place: setting values and norms, maritime security, weapons of mass destruction, terrorism and transnational crime, defense cooperation, the ASEAN Regional Forum, and cooperation with the United Nations (Severino, 2006: 356). Regarding the proposed APSC, the majority of respondents exhibited their positive perception on its benefits (see Table 3). The survey showed that a great majority of those surveyed perceived the formation of ASC as good for their country and society. More specifically, twothirds of them showed optimism that ASC would beneficial in making each member fully committed to the peaceful resolution of differences and conflicts. Likewise, almost three-quarters of the respondents also indicated that the APSC would be useful for regional cooperation in combating transnational security problems, such as terrorism, drugs trafficking, trafficking in persons, and cross border crimes.

Deeper economic integration was envisaged in the Bali Concord II, which described the ASEAN Economic Community (AEC) as the second pillar (ASEAN Secretariat, 2003). The AEC was described as a single market and production base with free flow of goods, services, investments, capital and skilled labour. The Blueprint of the AEC outlined four key goals, those are: (1) a single market and production base; (2) a highly competitive economic region; (3) a region of equitable economic development; and (4) a region fully integrated into the global economy. Regarding the AEC, the majority of respondents showed their positive perception. Nearly three-quarters of those surveyed perceived that their countries would benefit from membership in AEC (See Table 3). More specifically, about a great majority of them perceived the formation as good or positive to the people and for the business in their country. In addition, $72 \%$ respondents (74\% Malaysians, $75 \%$ Indonesians and 62\% Singaporeans) believed that AEC would lead to greater competitiveness to the region.

Declaration of Bali Concord II also aspired for the third pillar, the ASEAN Socio-Cultural Community (ASCC), to keep the Southeast-Asian bonded together in partnership as a community of caring societies (ASEAN Secretariat, 2003). The tenth ASEAN Summit in Vientiane, Laos, pursued the Vientiane Action Programme (VAP) for $2004-2010$ that emphasizes the action programmes for ASCC under four major thrust: (1) building a community of caring societies; (2) managing the social impact of economic integration; (3) promoting environmental sustainability; and (4) promoting an ASEAN identity. Further, the 2009 ASEAN Socio-Cultural Community Blueprint emphasizes that the ASCC envisages six characteristics: human development, social welfare and protection, social justice and rights, ensuring environmental sustainability, building the ASEAN identity, and narrowing the development gap. Regarding the ASCC, nearly threequarters of the respondents perceived that the formation of ASCC would be good for the social and cultural development of their country (See Table 3). Respondents showed their beliefs that ASCC would bring about positive results in terms of the increase of the variety and richness of ASEAN Culture, the creation of a caring community, and the improvement of the health of the people in the region.

\subsection{Supports for the Formation of the ASEAN Community}

In this study, support was defined as the position hold by the public on the formation of the ASEAN Community and its three pillars. In general, the study found that the respondents highly supported the proposed ASEAN Community (see Table 4). A great majority of respondents in the three countries surveyed supported the establishment of the ASEAN Community. Specifically, more than three-quarters respondents in three countries supported the formation of APSC. Regarding the economic regional integration, about $73 \%$ to $85 \%$ respondents supported the AEC. Furthermore, between $70 \%$ and $79 \%$ respondents supported the formation of ASCC. 
Table 4: Supports for the formation of the ASEAN Community

\begin{tabular}{|c|c|c|c|c|c|c|}
\hline & & & \multicolumn{4}{|c|}{ Respondents } \\
\hline & & & Malaysia & Indonesia & Singapore & Average \\
\hline \multirow{3}{*}{ I support the formation of the ASEAN Community. } & $\bullet$ & Mode & Agree & Agree & Agree & Agree \\
\hline & $\bullet$ & Mean & 4.05 & 4.14 & 4.00 & 4.08 \\
\hline & & & Agree & Agree & Agree & Agree \\
\hline \multirow{3}{*}{ I support the formation of the APSC. } & $\bullet$ & Mode & Agree & Agree & Agree & Agree \\
\hline & $\bullet$ & Mean & 3.92 & 4.00 & 3.84 & 3.94 \\
\hline & & & Agree & Agree & Agree & Agree \\
\hline \multirow{3}{*}{ I support the establishment of AEC. } & $\bullet$ & Mode & Agree & Agree & Agree & Agree \\
\hline & $\bullet$ & Mean & 4.00 & 3.96 & 3.81 & 3.94 \\
\hline & & & Agree & Agree & Agree & Agree \\
\hline \multirow{3}{*}{ I support the formation of ASCC. } & $\bullet$ & Mode & Agree & Agree & Agree & Agree \\
\hline & $\bullet$ & Mean & 3.89 & 3.89 & 3.82 & 3.87 \\
\hline & & & Agree & Agree & Agree & Agree \\
\hline
\end{tabular}

Source: Result of field surveys conducted by the researchers

\subsection{Perception on the Formation Process of ASEAN Community}

While the survey results have showed that the idea of the ASEAN Community was supported by the majority of the respondents, it is interesting to observe the respondents' views on the formation process of the ASEAN Community. Several scholarly works - like Amitav Acharya (2003), Claire Sutherland (2009), Guido Benny, Rashila Ramli and Than Siew Yean (2014), Jenina Joy Chavez (2007), Kamarulnizam Abdullah and Guido Benny (2013), Kamarulnizam Abdullah, Guido Benny, and Mohamed Anwar Omar Din (2013), Lily Zubaidah Rahim (2008), Melly Caballero-Anthony (2009), Ravichandran Moorthy and Guido Benny (2013), Rodolfo Severino (2007), Sung Won Kim (2010), and Thi Thu Huong Dang (2008) - had affirmed the ASEAN Community formation process as elitist and state-centric; it had yet to involve the people directly. Their argument is that only leaders, bureaucrats, and businesspeople have been deciding the course of the ASEAN Community creation (Benny and Abdullah, 2011). Amitav Acharya (2009), for example, asserted that it was the elite groups that had controlled most of the countries as the political system of illiberal non-democracy existed in most ASEAN countries. Both writers argued that the elite groups had been able to manipulate the social consciousness in the region for the purpose of creating a pacific union, similar to the one which had been socially constructed by liberal democracies. Thus, it is quite important to gauge the opinion to the process of fostering greater regional integration.

Table 5: Perception on the formation process of ASEAN Community

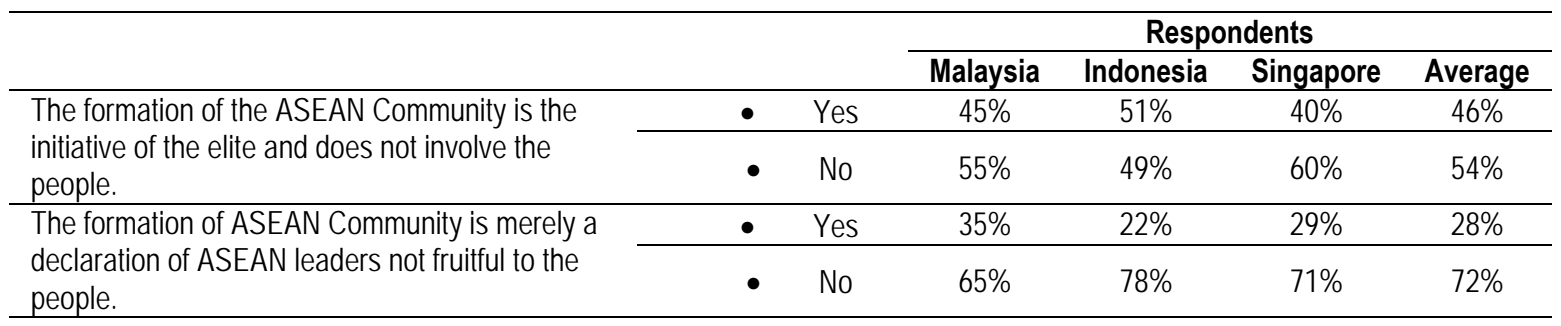

Source: Result of field surveys conducted by the researchers

The result of survey, as indicated in Table 5, provides additional support for the above stated stand. For example, more than half of Indonesian respondents admitted that the formation of ASEAN Community was the initiative of the elite and did not involve the public in its creation. While the majority of Malaysian and Singaporean respondents did not fully concur with their Indonesian counterparts, there were still a significant number who hold the same opinion with the majority of the Indonesian respondents. However, this did not appear to undermine the perceived benefit of the initiatives, as almost three-quarters of them admitted that the ideas would be fruitful to the people. This perception was also 
consistent with the finding about public perception of the benefits of ASEAN Community. Hence, it can be concluded that, while the formation process of ASEAN Community was perceived to be elitist, the respondents were still committed to its formation since it was perceived to benefit the people.

\subsection{Effect of Perception of the Elitist State-Centric Formation Process on Perceived Benefits and Support}

The study is aimed to discuss the effect of the opinion of the formation process that does not involve the people on perception of benefits and the support for the establishment of ASEAN Community. It was hypothesized that the opinion of the formation process would influence the perception of benefits and public supports for ASEAN Community.

Analysis of the survey data using the chi-square tests on the relationship between the opinion of the formation process and the perceived benefits from ASEAN Community is exhibited at Table 6(A). With some exception in the relationship with formation of APSC, the analysis of chi-square tests has indicated that significant positive relationship between opinion of the formation process and perceived benefits. Had the respondents perceived the formation as involving the people, their perceived benefits would be higher.

Table 6: The result of chi-square tests on the effects of the perception of the formation process on perceived benefits and supports for the ASEAN Community

\begin{tabular}{|c|c|c|c|c|c|}
\hline & & \multicolumn{3}{|c|}{ Pearson Chi Square } & \multirow[b]{2}{*}{ Result of analysis } \\
\hline & & Value & df & $\begin{array}{l}\text { Asymp.Sig (2- } \\
\text { sided) }\end{array}$ & \\
\hline A. & \multicolumn{5}{|c|}{$\begin{array}{l}\text { Relationships between 'the perception that the formation of the ASEAN Community does not involve the } \\
\text { people' and the indicators of perceived benefits: }\end{array}$} \\
\hline$\bullet$ & $\begin{array}{l}\text { My country will get benefits from the membership of } \\
\text { the ASEAN Community. }\end{array}$ & 16.218 & 4 & 0.003 & $\begin{array}{l}\text { Significant } \\
\text { relationship }\end{array}$ \\
\hline & $\begin{array}{l}\text { The establishment is good for my country and the } \\
\text { people. }\end{array}$ & 13.870 & 4 & 0.008 & $\begin{array}{l}\text { Significant } \\
\text { relationship }\end{array}$ \\
\hline$\bullet$ & $\begin{array}{l}\text { The formation of APSC is good for my country and } \\
\text { society. }\end{array}$ & 6.018 & 4 & 0.198 & $\begin{array}{l}\text { No significant } \\
\text { relationship }\end{array}$ \\
\hline & $\begin{array}{l}\text { My country will get benefits from membership in } \\
\text { AEC. }\end{array}$ & 18.424 & 4 & 0.001 & $\begin{array}{l}\text { Significant } \\
\text { relationship }\end{array}$ \\
\hline & $\begin{array}{l}\text { ASCC is good for the social and cultural } \\
\text { development of my country. }\end{array}$ & 10.065 & 4 & 0.039 & $\begin{array}{l}\text { Significant } \\
\text { relationship }\end{array}$ \\
\hline B. & \multicolumn{5}{|c|}{$\begin{array}{l}\text { Relationships between 'the perception that the formation of the ASEAN Community does not involve the } \\
\text { people' and the indicators of supports: }\end{array}$} \\
\hline & $\begin{array}{l}\text { Support for the establishment of ASEAN } \\
\text { Community }\end{array}$ & 9.461 & 4 & 0.051 & $\begin{array}{l}\text { Significant } \\
\text { relationship }\end{array}$ \\
\hline$\bullet$ & $\begin{array}{l}\text { Support for the establishment of ASEAN Political } \\
\text { Security Community (APSC) }\end{array}$ & 8.388 & 4 & 0.078 & $\begin{array}{l}\text { Significant } \\
\text { relationship }\end{array}$ \\
\hline & $\begin{array}{l}\text { Support for the establishment of ASEAN Economic } \\
\text { Community (AEC) }\end{array}$ & 12.841 & 4 & 0.012 & $\begin{array}{l}\text { Significant } \\
\text { relationship }\end{array}$ \\
\hline & $\begin{array}{l}\text { Support for the establishment of ASEAN Socio- } \\
\text { Cultural Community (ASCC) }\end{array}$ & 9.485 & 4 & 0.050 & $\begin{array}{l}\text { Significant } \\
\text { relationship }\end{array}$ \\
\hline
\end{tabular}

Source: Result of field surveys conducted by the researchers

The similar analysis on the data of the perceived benefits also showed that, in general, the perception of the formation process might have influenced the perception of benefits of ASEAN Community. Analysis of the survey data using the chi-square tests on the relationship between the opinion of the formation process and the support is exhibited at Table $6(B)$. The scores of the chi-square tests indicated the significant relationships between the opinion and the supports for the formation of ASEAN Community and its three pillars. Thus, it is implied that if the formation had been perceived as involving the people, there would be more supports for the formation. 


\section{Conclusion}

The study argues that public perception of benefits, supports, and perception of the formation process of the ASEAN Community need to be studied in order to plan effective strategies for its formation. This study has found that the respondents' perception of benefits, which was positive, was related to their perception of the formation process of the ASEAN Community. They also exhibited their support for the ASEAN Community although the formation process did not involve the public; however, the study found that, if the formation process had involved the people more actively, their perception of benefits and level of supports for the regional community would be higher.

Two implications can be inferred from the study. The first implication is on the public support and perception of benefits for the ASEAN Community. Although it is arguable that the public has perceived the formation of ASEAN Community as beneficial and they support it, we must put into our mind that the public opinion may change over time. Thus, ASEAN Secretariat - together with national governments - needs to formulate effective strategies to maintain positive public perception and supports for ASEAN Community. To find out the actual aspiration and attitudes of the public, the ASEAN Secretariat need to establish an agency to conduct regular 'ASEANbarometer' public opinion surveys in the ASEAN countries, so that the decision making for ASEAN Community can be based on the expectations of the people. The survey is considered the best measure because, given the current plurality of political systems of ASEAN countries, it is impossible to conduct direct voting like as in the European Union. Without the regular surveys, the real perception, opinion, and supports of the public will never be known and it will be more difficult to make effective decisions that cater to the needs and wants of the public.

The second implication is related to the perception that the formation process of the ASEAN Community did not involve the public. The perception is more serious in Indonesia than in Malaysia and Singapore since the perception is higher in this largest and most populated country in ASEAN. The finding indicates that the Indonesian government might have neglected its public in the formation process of the ASEAN Community. This is of concern because the democratic system that Indonesia has embraced requires more public involvement - something that might have yet to occur when the Indonesian government formulated the ASEAN Community together with their counterparts in the other ASEAN countries. So, the Indonesian government needs to pursue its efforts at socializing the ASEAN Community more aggressively and work together with civil societies to prepare the public to face regional integration. It is also suggested that the Indonesian government ought to involve the public more intensively when they make major decisions about the regional community.

\section{Acknowledgement}

This publication was supported by the Malaysian Ministry of Education Fundamental Research Grans Scheme (FRGS) No. FRGS/1/2012/SS04/UKM/02/2 titled 'Revisiting "Interdependancy Theory" in Explaining Malaysia's External Relations.

\section{References}

Abdullah, K, \& Benny, G. (2013). Regional public opinion towards the formation of political security community in Southeast Asia. Asian Journal of Scientific Research 6(4), 650-665.

Abdullah, K, Benny, G. \& Din, M. A. O. (2010). The understanding of the idealization and conceptualization of ASEAN Community: Comparative study between Malaysia and Indonesia," Tamkang Journal of International Affairs 14(2), 91-129.

Abidin, M. Z., Mooi, L. G. \& Aziz, N. I. A. (2012). Achieving the AEC 2012: Challenges for the Malaysian Private Sector. In S. B. Das (ed.), Achieving the ASEAN Economic Community 2015 (pp.196 - 223). Singapore: Institute of Southeast Asian Studies.

Acharya, A. (2003). "Democratisation and the prospects for participatory regionalism in Southeast Asia," Third World Quarterly 24, no. 2: 375-390.

Acharya, A. (2009). Constructing a Security Community in Southeast Asia: ASEAN and the Problem of Regional Order, 2nd ed. (New York: Routledge, 2009);

ASEAN Secretariat. (1997). ASEAN Vision 2020. Jakarta: ASEAN Secretariat.

ASEAN Secretariat. (2003). Declaration of Bali Concord II. Jakarta: ASEAN Secretariat.

Benny, G. \& Abdullah, K. (2011). Indonesian perceptions and attitudes toward the ASEAN Community." Journal of Current Southeast Asian Affairs 30(1), 39-67.

Benny, G., Rashila, R. \& Tham, S.Y. (2014). Nationalist Sentiments and Perceived Threats: Public Opinion in Indonesia, Malaysia and Singapore and Implications to the Establishment of ASEAN Community." Tamkang Journal of International Affairs XVIII(I), 59108.

Cabellero-Anthony, M. (2009). "Evolving regional governance in East Asia: From ASEAN to an East Asian Community", in Governance 
and Regionalism in Asia, ed. Nicholas Thomas (Taylor \& Francis).

Chavez, J.J. (2007). "Global social policy forum: Civil society challenging ASEAN", Global Social Policy 7(3): 260-262.

Chongkittavorn, K. (2006). "The Politics of speed: an ASEAN Community by 2015?", The Nation, 27 November, http://www. nationmultimedia.com/2006/11/27/opinion/ opinion_30020037.php, (accessed 28 April 2010).

Christensen, L. B., Johnson, R. B. \& Turner, L. A. 2011. Research Methods, Design, and Analysis, 11th edn. Boston: Allyn \& Bacon.

Collins, A. 2008. A people-oriented ASEAN: a door ajar or closed for civil society organisations? Contemporary Southeast Asia 30, no. 2 (2008).

Gabel, M.J. 1998. "Public support for European integration: An Empirical test of five theories," Journal of Politics 60(2): 333-354.

Gravetter, F. J., \& Wallnau, L. B. (2013). Statistics for the Behavioral Sciences, Ninth Edition. Wadsworth: Cengage Learning.

Guerrero, R. B. (2008). Regional integration: the ASEAN Vision in 2020. IFC Bulletin 32, 52-58.

Hew, D. (2007). Brick by brick: The building of an ASEAN Economic Community. Singapore: Institute of Southeast Asian Studies.

Jones, E. 2009. "Output legitimacy and the global financial crisis: Perceptions matter," Journal of Common Market Studies 47, no. 5: $1085-1105$.

Kompas, 2009. "Menjadikan ASEAN membumi", 2 March.

Moorthy, R. \& Benny, G. (2012a). Attitude towards community building in Association of Southeast Asian Nations: a public opinion survey. American Journal of Applied Science 9, 557-562.

Moorthy, R. \& Benny, G. (2012b). Is 'ASEAN Community' achievable? a public perception analysis in Indonesia, Malaysia and Singapore on the perceived obstacles for a regional community. Asian Survey 52(6), 1043-66.

Moorthy, R. \& Benny, G. (2013). Does public opinion count? Knowledge and support for an ASEAN Community in Indonesia, Malaysia, and Singapore. International Relations of the Asia-Pacific 13(3), 399-423.

Mugijayani, W. \& Kartika, P. (2012). Perspective of the Indonesian Business Sector on the Regional Integration Process. In S. B. Das (ed.), Achieving the ASEAN Economic Community 2015 (pp.196 - 223). Singapore: Institute of Southeast Asian Studies.

Pagano, R. R. (2013). Understanding Statistics in the Behavioral Sciences, Tenth Edition. Wadsworth: Cengage Learning.

Rahim, L.Z. 2008. "Fragmented community and unconstructive engagements", Critical Asian Studies 40(1): 67-88.

Severino, R.C. 2006. Southeast Asia in search of an ASEAN Community: Insights from the former ASEAN secretary general (Singapore: Institute of Southeast Asian Studies).

Severino, R.C. 2007. "ASEAN beyond forty: towards political and economic integration," Contemporary Southeast Asia: A Journal of International \& Strategic Affairs 29(3): 406-423.

Sung, W.K. 2010. "Human Security with an Asian Face?" Indiana Journal of Global Legal Studies 17(1): 83 - 103.

Sutherland, C. 2009. "Reconciling nation and region: Vietnamese nation building and ASEAN regionalism," Political Studies 57(2): 316336.

Thi, T.H.D., 2008. Examining the Engagement Between Civil Society in Southeast Asia and ASEAN in the ASEAN Community Building Process (GRIN Verlag).

Thompson, E. C. \& Thianthai, C. (2008). Attitudes and Awareness toward ASEAN: Summary of Findings from a Ten Nation Survey. Jakarta: The ASEAN Foundation.

Wilson, C.J. 2004. "Symbolic attitudes and regional integration in North America: Challenges and opportunities", paper presented at the IRPP Conference on North American Integration, April 1-2 2004, http://www.irpp.org/events/archive/ apr04/wilson.pdf, last accessed 3 January 2012. 